\title{
Investigating Finance-Growth Nexus: Further Evidence from Nigeria
}

\author{
Adeola Yahya Oyebowale ${ }^{1,3} \&$ Noah Kofi Karley ${ }^{2}$ \\ 1 Doctoral Researcher, Department of Economics and International Business, Lord Ashcroft International \\ Business School, Anglia Ruskin University, Cambridge, UK \\ ${ }^{2}$ Senior Lecturer, Department of Economics and International Business, Lord Ashcroft International Business \\ School, Anglia Ruskin University, Cambridge, UK \\ ${ }^{3}$ Lecturer, Department of Business and Management, University Campus Barnsley, UK \\ Correspondence: Adeola Yahya Oyebowale, Department of Economics and International Business, Lord Ashcroft \\ International Business School, Anglia Ruskin University, East Road, Cambridge, CB1 1PT, UK. Tel: \\ 447-432-489-111. E-mail: adeola.oyebowale@pgr.anglia.ac.uk
}

Received: August 5, 2018

Accepted: August 19, 2018

Online Published: August 25, 2018

doi:10.5539/ijef.v10n9p121

URL: https://doi.org/10.5539/ijef.v10n9p121

\begin{abstract}
This study investigates the influence of financial sector development on economic growth in Nigeria during the period 1982 to 2015. As such, the study obtained annual secondary data from the Central Bank of Nigeria statistical bulletins and World Bank financial database. The empirical model for this study examines growth in savings, growth in exchange rate, growth in government expenditure, growth in stock market capitalization, growth in credit to private sector, growth in gross capital formation, growth in trade openness and growth in broad money on economic growth in Nigeria. The multiple regression output reveals that growth in government expenditure and growth in gross capital formation are statistically significant on economic growth in Nigeria at $1 \%$ and $10 \%$ respectively under the period under investigation while other regressors in the model prove to be statistically insignificant. VAR test shows that there is considerable short-run causality running from lags of regressors to economic growth in Nigeria except for lag 1 of growth in exchange rate and lag 2 of growth in credit to private sector. The granger causality test reveals the existence of bi-directional causality between financial sector development and economic growth in Nigeria during the period under investigation. Hence, this study supports the 'feedback hypothesis' view on finance-growth. Based on these empirical results, this study recommends effective channeling of funds to the private sector and autonomy of the Central Bank of Nigeria in the use of monetary policy tools.
\end{abstract}

Keywords: financial sector development, economic growth

\section{Introduction}

Over the years, the relationship between financial development and economic growth has been one of the most debated issues in economics which is based on the special intermediary role of financial institutions between savers and lenders (Kar, Nazlioglu, \& Agir, 2011; Adu, Marbuah, \& Mensah, 2013). As such, several existing studies have examined whether financial sector actually contributes to the process of economic growth in both developing and developing economies For instance, studies such as Gregorio and Guidotti (1995), Demetriades and Hussein (1996), Odedokun (1996), Odedokun (1998), Levine (2002), Hao (2006), Mahran (2012), Liang and Reichert (2012), Bist (2018) have shown that financial sector development play an important role in promoting economic growth. The view of Liang and Reichert (2012) argues that the broad classification of financial structure (market-based or bank-dominated) which provides more effectiveness in promoting economic development remains unclear. This is due to the fact that the fundamental functions of a financial system in an economy can be performed by several types of institutions existing under several various sets of regulations (Liang \& Reichert, 2012).

By the same token, Nwanyanwu (2010) postulates that the existence of financial system in an economy aids the provision of the needed credit to economic agents through various financial institutions. Affirming this postulation, Mamman and Hashim (2014) accentuates that the financial system plays a significant role in mobilizing and channelling of funds to the real sectors existing in an economy. As such, financial system comprises of institutions such as stock market, banks, insurance and other financial institutions (Mamman \& 
Hashim, 2014). In Nigeria, the banking sector is an essential component of the Nigerian financial system; the banking sector accounts for about 90 percent of the total assets in the Nigerian financial system and about 60 percent of market capitalization in the Nigerian Stock Exchange (Alabede, 2012).

In the Nigerian banking system, commercial banks are essential as they perform dual significant role of wholesale and retail banking by providing aid to commercial and economic activities (Arnold, 2012; Modebe, Ugwuegbe, \& Ugwuoke, 2014). According to Korkmaz (2015), the existence of banks in an economy appears as service businesses mainly due to the role of intermediation between the savings surplus units and savings deficit units. Furthermore, Korkmaz (2015) highlights that the intermediation role of banks is to provide an increase in investments which makes savings important in ensuring economic growth. However, sufficient increase in savings has been impracticable in developing countries like Nigeria and the Sub-Saharan Africa region over the past three decades due to increasing scarcity of foreign aid (Loayza, Schmidt-Hebbel, \& Serven, 2000). The view of Korkmaz (2015) which in line with Lu and Shen (2012), emphasizes that the existence of an advanced and well-functioning financial system accelerates the flow of information between lender and borrower. Hence, it can be argued that risk diversification is encouraged for both saving and investing entrepreneurs.

According to Korkmaz (2015), in the history of economics, the emergence of banking commenced during the $15^{\text {th }}$ and $16^{\text {th }}$ centuries with the development of exchanger stores. However, in the $19^{\text {th }}$ century, there has been significant development exhibited by banks within historical process which has made banks become more regulated institutions. Consequently, banks have been providing aid to commercial and economic activities (Modebe, Ugwuegbe, \& Ugwuoke, 2014). Furthermore, Korkmaz (2015) asserts that the widely existence of a non-fragile and smooth operation of financial structure in developing countries has become one of the most essential indicators for economic growth. In the light of this assertion, banks operating in the financial structure of developing countries are tagged as institutions which foster economic life (Orji, Imelda, \& Mba, 2015; Korkmaz, 2015).

Focusing on the case study of this research, the Nigerian economy over the years has been faced with retarded economic growth just like many other less developed countries resulting from high regulation which has caused financial disintermediation (Orji, Imelda, \& Mba, 2015). According to Trading Economics (2018), the annual growth rate of GDP in Nigeria from 1982 to 2018 is on average of 3.88 percent, attaining a high record of 19.17 percent in fourth quarter of 2004 and a low record of -7.81 percent during the fourth quarter of 1983. In 2016Q1, the Nigerian economy slipped into recession with a GDP growth of -1.6 percent in response to drastic drop in global oil prices from a peak of $\$ 115$ per barrel in June 2014 to below $\$ 35$ by end of February 2016 (Rogoff, 2016; African Development Bank, 2017). The incessant unfavourable economic situation in Nigeria has led to the introduction of Economic Recovery and Growth Plan (ERGP) by the Federal Government on $7^{\text {th }}$ of March, 2017 (ACIOE, 2017; Templars, 2017). The aim of the plan is to restore economic growth in the medium term (2017 to 2020) with priority for five different objectives: stabilizing macroeconomic environment, ensuring sufficient energy, sustaining agriculture and food security, fostering industrialization through SMEs and improving transportation infrastructure. As such, the Nigerian economy eventually recuperated from recession in 2017 with a GDP growth of 0.8 percent following increase in oil prices and stronger performance of the agricultural sector (African Development Bank, 2018).

Be that as it may, the main epitome of this study emanates from existing studies conducted in Nigeria such as Ndako (2010), Oriavwote and Eshenake (2014), Modebe and Ezeaku (2016), Akpan, Nwosu, and Eweke (2017) and other studies conducted in other countries such as Gregorio and Guidotti (1995), Demetriades and Hussein (1996), Ahmed and Ansari (1998), Yang and Yi (2008), Kar, Nazlioglu,and Agir (2011), Mahran (2012), Zhang, Wang, and Wang (2012), Uddin, Sjo, and Shahbaz (2013). These studies have investigated financial sector development and economic growth using different empirical models. While some studies have used GDP as a dependent variable, some have used growth rate in real GDP as a dependent variable. However, the independent variables in the models were used in different units of measurement. Thus, the validity of such research findings and robustness of such empirical models are questionable and could be argued as vague.

It is against this backdrop that this study seeks to contribute to existing studies by using an empirical model comprising of dependent and independent variables in growth form. Additionally, this study will integrate some variables which have not been considered as determinants of economic growth in the econometric models of existing studies.

\section{Literature Review}

\subsection{Causality Views on Finance-Growth Nexus}

The incessant scholarly attention on finance-growth nexus is explained by four different causality views which 
emanated from the pioneering studies of Bagehot (1873) and Schumpeter (1911). The view of Bagehot (1873) pinpoints the significant role of the banking system in facilitating economic growth and innovation through providing funds to productive investments. This assertion was based on the argument of Bagehot (1873) that the financial system performed a viral role in enhancing industrialisation through effective mobilisation of capital for the execution of massive works in England. Building on the postulation of Bagehot (1873), the eminent literature of Schumpeter (1911) accentuates that provision of financial services by the financial system augments economic growth and innovation. In line with the foregoing, this study highlights that the pioneer views of Bagehot (1873) and Schumpeter (1911) explains a unidirectional causality between finance and growth. This is so as the pioneer views focus on the significant role of financial institutions in the supply of funds to economic agents for productive use in order to enhance economic growth. Hence, the aforementioned studies propose the finance-led growth view where economic growth follows finance.

The finance-led growth view is supported by the ensuing studies of Goldsmith (1969), McKinnon (1973) and Shaw (1973). The study of Goldsmith (1969) focuses on the relevance of investment efficiency, while the studies of McKinnon (1973) and Shaw (1973) focus on relevance of financial liberalisation in facilitating savings and investment. According to Adu, Marbuah and Mensah (2013), the studies of McKinnon (1973) and Shaw (1973) encouraged several developing countries to adopt liberalisation in the financial system. For instance, Nigeria became a member of International Monetary Fund (IMF) on 30 ${ }^{\text {th }}$ of March, 1961 (IMF, 2017) and launched the Structural Adjustment Programme (SAP) in 1986 under the military regime of General Ibrahim Babangida.

As a contribution to the ongoing debate, a later study of Robinson (1952) argues the views of Bagehot (1873) and Schumpeter (1911) by considering finance as an insignificant factor in the process of economic growth. In this regard, Robinson (1952) asserts that as output increases, the demand for financial services increases which simultaneously enhances financial development. Thus, the later study of Robinson (1952) proposes a unidirectional growth-led finance view where finance follows economic growth.

In a reuniting approach, Patrick (1966) contributes to the debate on finance-growth nexus by acknowledging the finance-led growth paradigm of Bagehot (1873) and Schumpeter (1911) on the one hand; and the growth-led finance paradigm of Robinson (1952) on the other hand. As such, Patrick (1966) explains the existence of causality in finance-growth nexus using two set of hypotheses: supply-leading and demand-following. In this regard, the supply-leading hypothesis supports the finance-led growth paradigm as it reinforces the availability of a stable financial system ahead of demand for its services to aid channelling of funds to productive use. Furthermore, Patrick (1966) accentuates that the supply-leading paradigm performs two key functions: channelling resources from non-growth or traditional sectors to modern sectors, and to facilitate the response of entrepreneurs to modern sectors. In recent literature, this finance-led growth view or supply-leading paradigm is supported by studies such as: Marashdeh and Al-Malkawi (2014), Kumar (2014), Fethi and Katircioglu (2015), and Deyshappriya (2016), among others.

In contrast, the demand-following hypothesis supports the growth-led finance view as it acknowledges a causal relationship from economic growth to financial development through the demand for financial services. As such, this view posits that as economic growth increases through existing sectors of an economy, the demand for modern financial services increases which enhances growth of the financial sector (Patrick 1966). Hence, finance is passive in the process of economic growth (Patrick 1966). This growth-led finance view or demand-following hypothesis is supported by studies such as: Hassan, Sanchez, and Yu (2011), Ndlovu (2013), Pan and Mishra (2018), Nasir, Majeed, and Aleem (2018), and Bist (2018), among others.

Following the supply-leading and demand-following hypothesis, Patrick (1966) accentuates that an interaction between the two paradigms is possible, this interaction is regarded as stage of development hypothesis. As such, supply-leading plays a significant role in enhancing economic growth at the early stages by encouraging real investment within an economy through channelling of funds. Progressively, supply-leading becomes less important as economic growth increases and demand-following takes over as economic agents demand for more modern financial services at later stages. As such, this stage of development hypothesis as proposed by Patrick (1966) explains bidirectional causality between finance and growth which initiates the third finance-growth nexus view of 'feedback hypothesis'. This bidirectional view or feedback hypothesis is supported by existing studies such as: Calderon and Liu (2003), Ndako (2010), Ogbonna et al. (2013), Hassan, Sanchez, and Yu (2011), Adeyeye et al. (2015), Kyophilavong, Uddin, and Shahbaz (2016), and Abosedra and Sita (2018), among others.

Contrary to the discussed three views, the fourth view on finance-growth nexus is the 'neutrality hypothesis' which is renowed by Lucas (1988). As such, this view argues that the role of financial development on economic growth is exaggerated and there is no causal relationship existing between the two variables. This view is 
supported by studies such as: Akbas (2015), Nyasha and Odhiambo (2015), Adeniyi et al. (2015) and Pradhan (2018), among others.

\subsection{Empirical Evidences}

The study of Odedokun (1996) examines the effects of financial intermediation on economic growth in 71 countries using annual data over different periods spanning over 1960s and 1980s. As such, the study adopted two different empirical models based on the Solow-swan neo-classical model of economic growth as defined below:

The first model comprises of $Y=$ growth in real GDP, $L=$ growth in labour force, $(I / Y)=$ share of real gross investment $(I)$ in the real GDP $(\mathrm{Y}), F$ = growth in wide money stock or annual growth rate of end-of-year real stock of liquid liabilities as measure of financial development, $X=$ growth in real exports.

The second model includes $F(F / Y)=$ product of financial intermediation growth $(F)$ and financial depth $(F / Y)$ as a regressor. The models were estimated using OLS regression techniques. The study reveals that financial intermediation influences economic growth in about $85 \%$ of the countries under investigation. Also, the study reveals that financial intermediation is at par practically with export expansion and capital formation ratio, I superiority to labour force growth as promoters of economic growth. Additionally, the study reveals that the influence of financial intermediation on economic growth is more predominant in low-income than high-income countries. Furthermore, the study reveals that the economic growth promoting effects of financial intermediation proves to be practically invariant across the different regions of the globe.

In addition to the above, Odedokun (1998) investigates the influence of financial intermediation on economic growth in developing countries. As such, two alternative measures of financial intermediation were employed in estimating the four equations for the study. The first measure is stock of domestic credit represented by domestic assets of the financial sector and the second is stock of liquid liabilities represented by domestic liability of the financial sector. The study reveals that growth of financial aggregates in real terms has positive impacts on economic growth in developing countries, financial deepening promotes economic growth in low-income developing countries but no perceptible influence on economic growth in high-income developing countries, the combined effects of financial intermediation on economic growth appears to be significantly positive, and the two postulated effect channels of financial intermediation are found to be applicable to the countries under investigation.

In China, the study of Hao (2006) investigates the development of financial intermediation and economic growth from 1985 to 1999 using set of traditional growth determinants (infrastructure, education and population growth) and indicators of financial intermediation development (ratio of the state banking sector's loans outstanding in relation to GDP, the ratio of household savings deposits in relation to GDP, and share of fixed asset investment financed by domestic loans in relation to those financed by state budgetary appropriation). The study reveals that substitution of loans for state budget appropriation and mobilization of household savings exhibits a significant positive relationship to economic growth in China. However, loan expansion proves to be insignificant on economic growth in China.

The study of Yang and Yi (2008) examines the causal relationship between financial development and economic growth in Korea using annual data between the period 1971 to 2002. As such, the research findings reveals that financial development causes economic growth while economic growth does not cause financial development in Korea. Hassan, Sanchez, and Yu (2011) investigates the role of financial development in Accounting for economic growth in low and middle income countries using a panel regression analysis. The study reveals that there is a positive relationship between financial development and economic growth in developing countries.

Kar, Nazlioglu, and Agir (2011) examines the direction of causality between financial development and economic growth in MENA countries using panel causality testing approach. The study reveals that there is no clear consensus on the direction of causality between financial development and economic growth. The study of Liang and Reichert (2012) expanded the Odedokun (1996) neo-classical model to include several complementary measures of financial sector development as defined below. The study reveals that non-bank financial institutions (NBFIs) have negative statistical influence on economic growth in both emerging and advanced countries using cross-country data which is consistent with the study of Cheng and Degryse (2010). Based on the result, Liang and Reichert (2012) argues that the negative impact of NBFIs one economic growth in driven by loose regulation of the sector which may introduce excessive risk into the financial sector and economy.

Additionally, the study of Mahran (2012) examines the relationship between financial intermediation and 
economic growth in Saudi Arabia within the time span of 1968 to 2010. This study uses natural logarithm of real GDP at 1999 prices as indicator of economic growth compared to growth rate of real GDP in earlier studies such as King and Levine (1993), Odedokun (1996), Odedokun (1998), and Rousseau and Wachtel (1998). The study of Mahran (2012) also uses bank credit to private sector as a superior measure of financial development by arguing in line with Gregorio and Guidotti (1995) and Levine, Loayza, and Beck (2000) that bank credit to private sector measures the quality and quantity of investment. As such, the study of Mahran (2012) considers three indicators of financial development: financial sector liquid liabilities (currency plus demand and interest-bearing liabilities of banks) as a ratio to nominal GDP, broad money supply as a percentage of GDP to measure the size and depth of financial intermediation activity, and credit to private sector as a ratio to nominal GDP.

Additionally, other variables in the model other than those related to financial development include gross investment as a percentage of GDP (INV), government spending as a percentage of GDP (G), human capital (H) and openess to trade (OPEN). Also, the study of Mahran (2012) reveals that financial intermediation has a significant negative impact on real GDP which is attributable to the structure and features of financial system in Saudi Arabia. In China, the study of Zhang, Wang, and Wang (2012) examines the relationship between financial development and economic growth at city level over the period 2001 to 2006. The result of the study reveals that most traditional indicators of financial development are positively associated with economic growth in China cities. Uddin, Sjo, and Shahbaz (2013) examines the relationship between financial development and economic growth in Kenya over the period of 1971 to 2011 . The outcome of the study reveals that financial development has a positive influence on economic growth in Kenya. Adu, Marbuah, and Mensah (2013) investigates the long-run effects of financial development in Ghana. The study reveals that credit to private sector as ratios to GDP and total domestic credit influences economic growth in Ghana while broad money stock to GDP proves to be insensitive to economic growth in Ghana.

The study of Modebe and Ezeaku (2016) examines the relationship between financial development and economic growth in Nigeria between 1987 to 2014. The study accommodates financial development indices such as banking credit to private sector as a percentage of real GDP, broad money as a percentage of real GDP, financial depth measured by total deposit as a percentage of real GDP, trade openness measured as sum of imports and exports in relation to real GDP, stock market capitalisation as a percentage of GDP and inflation and foreign direct investment. The dependent variable was measured using growth rate of real GDP at current basic prices. The study using regression analysis reveals that credit to private sector, inflation and stock market capitalization have negative impact on economic growth in Nigeria. However, trade openness, broad money and trade openness exert a positive influence on Nigerian economic growth.

Similarly, the study of Akpan, Nwosu, and Eweke (2017) employs credit to private sector, total bank deposit, prime lending rate, market capitalization, and money market instruments as proxy of financial sector development. Additionally, the study included non-oil export as a regressor on GDP. The study uses annual data from 1985 to 2015 and reveals that market capitalization, total bank deposit and credit to private sector have an impact on economic growth in Nigeria. The research of Bist (2018) examines long-run relationship between financial development and economic growth among selected 16 low-income countries for the period 1995 to 2014 using panel unit root and panel cointegration. The study reveals that there is existence of long-run cointegrating relationship between financial development and economic growth in the region under investigation. Additionally, the study finds evidence to support a positive and significant impact of financial development on economic growth. In the Caribbean context, the study of Ghartey (2018) finds evidence to support short-run role of financial development on economic growth in Barbados, Jamaica and Trinidad and Tobago. Furthermore, the study of Ghartey (2018) reveals demand-following hypothesis in Jamaica while results in Barbados and Trinidad and Tobago was mixed.

\section{Data and Model Specification}

For the purpose of this study, annual secondary data was collected from World Bank and Central Bank of Nigeria statistical bulletins for the longitudinal time horizon 1981 to 2015. However, the data used for this study have been computed using Microsoft Office Excel 2013 in order to generate the growth form of the variables. Hence, the data analysed for this study spans over 1982 to 2015 and data analysis was conducted using Stata version 13.1 software. In order to contribute to existing knowledge, this study integrates some new sets of regressors as shown in equation 1 below. Particularly, this study builds on existing studies conducted in Nigeria such as Modebe and Ezeaku (2016) and Akpan, Nwosu, and Eweke (2017).

$$
g G D P_{t}=\alpha_{0}+\alpha_{1} g E X R_{t}+\alpha_{2} g G E X_{t}+\alpha_{3} g G C F_{t}+\alpha_{4} g S M C_{t}+\alpha_{5} g C P S_{t}+\alpha_{6} g T O P_{t}+\alpha_{7} g B R M_{t}+\alpha_{8} g S A V_{t}+u_{t}(1)
$$


Where gGDp is growth in Real GDP, gEXR is growth in Official Exchange rate (N/USD), gGEX is growth in Government Expenditure, gGCF is growth in Gross Capital Formation, gSMC is growth in Stock Market Capitalisation, gCPS is growth in Credit to Private Sector, gTOP is growth in Trade Openness, gBRM is growth in Broad Money, gSAV is growth rate in Savings, $\alpha_{0}$ is the intercept, $\alpha_{1-8}$ is the slope of coefficient of regressors, $t$ is the time period and $\mu$ is error term.

\section{Results}

\subsection{Diagnostics}

This study conducted a unit root test developed by Dickey and Fuller (1979) as a procedure for examining whether a variables has a unit root or not. The null hypothesis is always stated that a variable has a unit root or not stationary. The ADF unit root test as shown in table 1 shows that all the variables under investigation values are stationary at level as the test statistic values are greater than $5 \%$ critical values. Furthermore, the coefficient of lag one is negative at level which means the model is valid. Hence, the null hypothesis is rejected which implies that the variables under investigation do not have unit root. The variables in the model have been computed to growth form before analysis which concurrently transforms the variables to first difference. However, for the purpose of this study, the result will be considered stationary at level.

Table 1. ADF unit root test result

\begin{tabular}{llcccc}
\hline Variable & Test Statistic & \multicolumn{3}{c}{ Critical Values } & \multirow{2}{*}{ Remark } \\
\cline { 3 - 5 } & & $1 \%$ & $5 \%$ & $10 \%$ & $\mathrm{I}(0)$ \\
gGDP & -4.447 & -3.696 & -2.978 & -2.620 & $\mathrm{I}(0)$ \\
gEXR & -5.469 & -3.696 & -2.978 & -2.620 & $\mathrm{I}(0)$ \\
gGEX & -5.908 & -3.696 & -2.978 & -2.620 & $\mathrm{I}(0)$ \\
gGCF & -5.196 & -3.696 & -2.978 & -2.620 & $\mathrm{I}(0)$ \\
gSMC & -4.793 & -3.696 & -2.978 & -2.620 & $\mathrm{I}(0)$ \\
gCPS & -4.515 & -3.696 & -2.978 & -2.620 & $\mathrm{I}(0)$ \\
gTOP & -7.434 & -3.696 & -2.978 & -2.620 & $\mathrm{I}(0)$ \\
gBRM & -3.563 & -3.696 & -2.978 & -2.620 & $\mathrm{I}(0)$ \\
gSAV & -4.742 & -3.696 & -2.978 & -2.620 & \\
\hline
\end{tabular}

Source: Authors' Computation (2018).

Also, serial correlationor autocorrelation test was conducted using Durbin-Watson and Breusch-Godfrey Tests in order to determine if error terms in the time series has been transferred from one period to another. Additionally, heteroskedasticity and multicollinearity tests were conducted. On the one hand, one of the key assumptions for an OLS regression is the existence of homogeneity of variance in the residuals; a well-fitted model should have no pattern to the residuals plotted against fitted values. As such, the null hypothesis for heteroskedasticity is stated as a constant variance or no heteroskedasticity in the formulated model. On the other hand, multicollinearity is the state of a very high inter-associations or inter-correlations among independent variables in an empirical model. Hence, it tends to be a type of data disturbance and the existence of multicollinearity in a data set of a model may not yield a reliable statistical inference (Belsley, 1991). Multicollinearity can be detected using the Variance Inflation Factor (VIF). According to Chatterjee and Hadi (2012), most analysts rely on the informal rules of thumb applicable to the use of VIF in detecting multicollinearity which are:

- VIF value greater than 10 shows multicollinearity problem

- The mean of all the VIFs should be greater than 1

The diagnostic results of serial correlation, heteroskedasticity and multicollinearity conducted to examine the reliability, consistency and efficiency of the model in equation 1 are shown in table 2 and 3 below.

Table 2. Autocorrelation and Heteroskedasticity test results

\begin{tabular}{|c|c|c|c|}
\hline \multicolumn{4}{|c|}{ Breusch-Godfrey LM Test for Autocorrelation } \\
\hline chi2 & 0.200 & Prob > chi2 & 0.6545 \\
\hline \multicolumn{4}{|c|}{ Durbin's Alternative Test for Autocorrelation } \\
\hline chi2 & 0.142 & Prob > chi2 & 0.7061 \\
\hline \multicolumn{4}{|c|}{ Breusch-Pagan /Cook-Weisberg Test for Heteroskedasticity } \\
\hline chi2 & 2.38 & Prob > chi2 & 0.1228 \\
\hline
\end{tabular}

Source: Authors' Computation (2018). 
Table 3. Multicollinearity test results

\begin{tabular}{lll}
\hline & VIF Test & \\
\hline Variable & VIF & 1/VIF \\
\hline gBRM & 2.84 & 0.352603 \\
gCPS & 2.38 & 0.419774 \\
gSAV & 2.38 & 0.419774 \\
gTOP & 1.46 & 0.684901 \\
gGEX & 1.39 & 0.718424 \\
gGCF & 1.28 & 0.780322 \\
gSMC & 1.19 & 0.842131 \\
gEXR & 1.16 & 0.864438 \\
Mean VIF & 1.76 & \\
\hline
\end{tabular}

Source: Authors' Computation (2018).

From table 2, Breusch-Godfrey and Durbin's alternative tests show a p-Value of 0.6545 and 0.7061 respectively. Hence, the null hypothesis of no serial correlation cannot be rejected as the p-values are greater than 5\%. This implies that the parameter estimates (regression coefficients) of the model will tend to be consistent and valid; hence, the model enhances right inferences to be drawn as regards the statistical output. Additionally, the Breusch-Pagan / Cook-Weisberg test indicates a p-value of 0.1228 indicating that the null hypothesis cannot be rejected as the p-value is greater than $5 \%$. Hence, there is existence of constant variance.

From table 3, the VIF values for all regressors are significantly below 10 and the mean VIF is greater than 1 . Following the assertion of Chatterjee and Hadi (2012), it is noted that the VIF test for this model fufills the two rules of thumb. Hence, it can be deduced that there is no multicollinearity problem in the model.

\subsection{Regression Analysis}

Based on the conduct of four essential diagnostic test for the model of this study (equation 1), it can be deduced that the model is fit and reliable for predicting the outcome of this study. As a progress, the study has deemed it fit to conduct other statistical tests towards the research aim of the study which commences with a regression analysis.

Table 4 shows multiple regression output for this study, the table reveals 34 observations in the regression analysis spanning from 1982 to 2015. Table 4 shows F-test as the ratio of regression mean square to residual mean square. It measures the overall significance of the model or assesses joint significance of the coefficients associated with the regressors. The F-test for this study shows a value of 0.0001 which is greater than 0.01 . This implies that the empirical model formulated for this study is statistically significant at $1 \%$ significant level and the coefficients of the regressors are jointly significant. Based on the outcome of the regression analysis, there is 99\% confidence that the null hypothesis can be rejected while the alternate hypothesis cannot be rejected. As such, it can further be deduced that the model is fit to make predictions or possess explanatory power as regards the topic under investigation.

Also, table 4 shows R-Squared or coefficient of determination, with a value of 0.7010 . This implies that $70.10 \%$ of variation in economic growth (gGDP) in Nigeria is explained or accounted for by the independent variables in the model (gEXR, gGEX, gGCF, gSMC, gCPS, gTOP, gBRM, and gSAV). Hence, other variables not explicitly stated in the regression model represented by error term (" $\mu$ ") account for $29.9 \%$ of variation in economic growth. In addition to this, table 4 further shows the p-value of the T-test of the individual independent variables on economic growth in Nigeria for the period under investigation. The p-values show that gGEX (0.000) and gGCF (0.080) are positively statistically significant on economic growth in Nigeria at $1 \%$ and $10 \%$ respectively within the time span under investigation. This is so as the p-value of 0.000 is less than 0.01 and 0.080 is less than $10 \%$. gGCF proves to be statistically insignificant at $1 \%$ and $5 \%$ but statistically significant at $10 \%$. However, gEXR, gSMC, gCPS, gTOP, gBRM and gSAV proves to be statistically insignificant on economic growth in Nigeria at $1 \%, 5 \%$ and $10 \%$ with P-values of $0.133,0.780,0.477,0.722,0.873$, and 0.462 respectively.

Additionally, table 4 shows the coefficients of the variables under investigation. The result reveals that every one unit increase in gGEX, gGCF, gTOP and gBRM has increased economic growth in Nigeria by $0.0005444 \%$, $0.0739455 \%, 0.0198453 \%$ and $0.0141783 \%$ respectively. Hence, there is a positive correlation among gGEX, gGCF, gTOP and gBRM, and economic growth in Nigeria. On the other hand, the result further shows that every one unit increase in gEXR, gSMC, gCPS and gSAV has decreased economic growth in Nigeria by $0.021836 \%$, 
$0.0059528 \%, 0.0363844 \%$ and $0.0497709 \%$ respectively. This shows a negative correlation among the independent variables and dependent variable. The standard error values of the coefficients are very low which shows high precision of the associated coefficients; hence, the signal-to-noise ratio of the coefficients is minimal which makes the coefficients suitable for prediction. Furthermore, table 4 further shows a constant coefficient value of 0.0538815 which is the level of economic growth in Nigeria assuming all independent variables in the formulated multiple regression model are zero during the period under investigation. Thus, economic growth in Nigeria is $0.0538815 \%$ without the influence of the independent variables in the empirical model or when the independent variables are assumed to be zero (" 0 ").

Table 4. Regression test results

\begin{tabular}{lll}
\hline Dependent Variable: Growth in real GDP & Coefficients & Standard Error \\
\hline Intercept & 0.0538815 & 0.0154161 \\
Growth in Exchange Rate & -0.021836 & 0.0140479 \\
Growth in Government Expenditure & $0.0005444^{* *}$ & 0.0000955 \\
Growth in Gross Capital Formation & $0.0739455^{*}$ & 0.0405216 \\
Growth in Stock Market Capitalization & -0.0059528 & 0.0210757 \\
Growth in Credit to Private Sector & -0.0363844 & 0.0504389 \\
Growth in Trade Openness & 0.0198453 & 0.0551274 \\
Growth in Broad Money & 0.0141783 & 0.0875781 \\
Growth in Savings & -0.0497709 & 0.0666284 \\
No of Observations & 34 & \\
R-Squared & 0.7010 & \\
Prob > F & 0.0001 & \\
\hline
\end{tabular}

Note. * Significant at $1 \%$ level, ** Significant at $10 \%$ level.

Source: Authors' Computation (2018).

\subsection{Johansen Cointegration}

This study has deemed it relevant to conduct the Johansen cointegration test in order to test the existence of long-run relationship among the variables under investigation. Co-integration analysis is related to multivariate analysis since it tends to be impossible for single time series to exhibit co-integration (Hendry \& Juselius, 2000). When co-integration exists among variables, it indicates that the variables may wander from one another in the short-run; however, the variables should move together in the long-run.

However, to test for cointegration or fit cointegrating VECMs among variables, there must be a specification for the number of lags to include. As such, Nielsen (2001) which builds on the studies of Tsay (1984) and Paulsen (1984) asserts that the methods which are implemented in "varsoc" command on stata can be used to determine the lag order for a VAR model when variables are stationary. "varsoc" computes four infromaiton criteria which include Final Prediction Error (FPE), Akaike Information Criterion (AIC), Hannan-Quinn Information Criterion (HQIC) and Schwarz Bayesian Information Criterion (SBIC), as well as sequence of Likelihood Ratio (LR) tests. Hence, the order of the corresponding VECM tends to always be one less than the VAR as the "vec" command automatically does adjustment (Nielsen, 2001). As shown in table 5 below, the AIC, HQIC and SBIC criteria indicates four lags, the LR criterion indicates two lags while the FPE criterion indicates three lags. As such, four lags will be used in the cointegration analysis for the system equation model of this study. This is because a maximum of three criteria indicates the selection of four lags for the model.

Table 5. Lag selection results

\begin{tabular}{cc}
\hline Selection Criterion & No. of Lag Selection \\
\hline LR & 2 \\
FPE & 3 \\
AIC & 4 \\
HQIC & 4 \\
SBIC & 4 \\
\hline
\end{tabular}

Source: Authors' Computation (2018). 
After determining the suitable lag selection for this model, table 6 shows the Johansen cointegration test result for the model under investigation. From table 6, the trace statistic fails to reveal values in relation to its critical value for all ranks while max statistic fails to show value for maximum rank of ' 0 '. As such, the trace and max statistic have not shown a specific number of cointegrating equations among the variables at 5\% significance level; hence, the null hypothesis of no cointegrating equation cannot be rejected. This implies that the variables in the system equation model are not cointegrated. As such, this means the variables have no long-run relationship and do not move together in the long run. Hence, a VAR (unrestricted) test will be conducted on the model under investigation. In a case where cointegration exists among the variables, the VECM (restricted VAR) test will be conducted.

Table 6. Johansen test for cointegration results

\begin{tabular}{ccccc}
\hline Trace Statistic & 5\% Critical Value & Max Statistic & 5\% Critical Value & Hypotheses \\
\hline- & 192.89 & - & 57.12 & $\mathrm{r}=0$ \\
- & 156.00 & 786.1756 & 51.42 & $\mathrm{r} \leq 1$ \\
- & 124.24 & 0.0000 & 45.28 & $\mathrm{r} \leq 2$ \\
- & 94.15 & 0.0000 & 39.37 & $\mathrm{r} \leq 3$ \\
- & 68.52 & 0.0000 & 33.46 & $\mathrm{r} \leq 4$ \\
\hline
\end{tabular}

Source: Authors' Computation (2018).

\subsection{Vector Autorgression Model (VAR)}

Table 7 shows the VAR test output of the variables, the result does not indicate long run causality as in the case of VECM since the variables are not cointegrated. However, the output shows the individual short-run causality between lagged values of independent variable to dependent variable by indicating the short-run coefficients and p-values. As such, from table 7, individual lag 2 and lag 3 of gEXR have short-run causality on gGDP with p-values of 0.000 each, while lag 1 of gEXR does not have a short-run causality on gGDP with a p-value of 0.653. There is also a short-run causality running from lag 1, lag 2 and lag 3 of gGEX to gGDP with p-values of $0.000,0.001$ and 0.000 respectively.

Also, there is a short-run causality running from lag 1, lag 2 and lag 3 of gGCF to gGDP with p-values of 0.000 each. Similarly, the output shows short-run causality running from lag 1, lag 2 and lag 3 of gSMC to gGDP with p-values of 0.000 each. Additionally, lag 1 and lag 3 of gCPS have short-run causality running to gGDP with p-values of 0.000 each; however, lag 2 of gCPS shows no short-run causality to gGDP. Furthermore, the result shows there is short-run causality running from lag 1, lag 2 and lag 3 of gTOP and gSAV to gGDP with P-values of 0.000 each. Lag 1 and Lag 2 of gBRM also shows a short-run causality running to gGDP while lag 3 of gBRM does not have a short-run causality to gGDP.

Table 7. VAR test results

\begin{tabular}{cccc}
\hline Variables to gGDP & Lag 1 & Lag 2 & Lag 3 \\
\hline gEXR & 0.653 & $0.000^{*}$ & $0.000^{*}$ \\
gGEX & $0.000^{*}$ & $0.001^{*}$ & $0.000^{*}$ \\
gGCF & $0.000^{*}$ & $0.000^{*}$ & $0.000^{*}$ \\
gSMC & $0.000^{*}$ & $0.000^{*}$ & $0.000^{*}$ \\
gCPS & $0.000^{*}$ & 0.918 & $0.008^{*}$ \\
gTOP & $0.000^{*}$ & $0.000^{*}$ & $0.000^{*}$ \\
gBRM & $0.000^{*}$ & $0.000^{*}$ & 0.089 \\
gSAV & $0.000^{*}$ & $0.000^{*}$ & $0.000^{*}$ \\
\hline
\end{tabular}

Note.* Significant at 5\% level.

Source: Authors' Computation (2018).

\subsection{Granger Causality Test}

In addition to the individual lagged values short-run causality as shown in table 7 , this study went further to conduct the granger causality test to show the combined causality between the lag values of the variables under investigation. The statistical concept of granger causality is wholly based on prediction. According to granger causality, if a variable " $\mathrm{X}$ " granger-causes another variable "Y", then the past values of " $\mathrm{X}$ " should encompass 
information which is useful in predicting "Y" (Seth, 2007).

Table 8 shows the granger causality test of the variables, the null hypothesis is stated as each independent variable does not granger cause economic growth in Nigeria. The test reveals that there is a short-run causality running from collective lag 3 values of gEXR, gGEX, gGCF, gSMC, gCPS, gTOP, gBRM, and gSAV to gGDP. This decision is based on the p-values of the variables which is 0.000 for all the variables as shown in table 10 . Hence, the null hypothesis is rejected as the p-values are less than 5\%. As such, it can be deduced that each independent variable granger cause economic growth in Nigeria. Additionally, the test shows that ALL the independent variables granger cause economic growth in Nigeria. In other words, financial sector development granger causes economic growth in Nigeria within the period under investigation.

Furthermore, the direction of causality between the dependent variable to the independent variables is revealed. As such, the output reveals that economic growth in Nigeria granger cause all the independent variables (gEXR, gGEX, gGCF, gSMC, gCPS, gTOP, gBRM, and gSAV) within the period under investigation as shown in table 8 below. Hence, the direction of causality between finance and growth in Nigeria for the period under investigation is bidirectional which provides evidence to support the 'feedback hypothesis' view.

Table 8. Granger causality test results

\begin{tabular}{lcc}
\hline Dependent variable & Independent variable & Direction of Causality \\
\hline gGDP & gEXR & Bidirectional \\
& gGEX & Bidirectional \\
gGCF & Bidirectional \\
gSMC & Bidirectional \\
gCPS & Bidirectional \\
gTOP & Bidirectional \\
gBRM & Bidirectional \\
gSAV & Bidirectional \\
\hline
\end{tabular}

Source: Authors' Computation (2018).

\section{Concluding Remarks}

Following the assertion of Mueller (1979), the significance of gGEX on economic growth in Nigeria can be argued as the provision of public goods which enhances productivity and voluntary exchange relationship through enforcement of property rights. Additionally, based on the assertion of Lin (1994), it can also be argued that government spending in Nigeria has interaction with the private sector which has helped to improve the allocation of resources and facilitate economic growth in Nigeria within the time span under investigation. Also, the significance of gGCF on economic growth in Nigeria is in line with the study of Pavelescu (2008). As such, this study affirms the assertion of Pavelescu (2008) that capital accumulation has a strong correlation with capital accumulation.

On the other hand, the insignificance of gTOP on economic growth in Nigeria can be argued as insufficient acceptance of globalisation and low openness to international exchange of goods and services despite Nigeria being endowed with oil. The main source of income to the Nigerian economy is from exportation of oil which has enhanced international trade with countries around the world especially the United States holding the largest percentage of Nigeria's oil exportation. Despite this, gTOP still proved to be insignificant on economic growth in Nigeria. Thus, this study argues that insignificance of trade openness on economic growth is Nigeria is attributable to the incessant embezzlement and corruption by public officials in Nigeria which supports the postulation of D'Agostino, Dunne, and Pieroni (2016).

Additionally, the essential role of Nigerian commercial banks in financing private sector of the economy appears to be debatable. Following the assertion of Levine, Loayza, and Beck (2000), credit to private sector is regarded as an exclusive measure of financial intermediation as it excludes credit issued to the government, its agencies and credit issued by Central Banks. This study reveals that gCPS does not have a significant impact on economic growth in Nigeria which can be argued as insufficient funding to the private sector of the economy. As such, this can be linked to strict conditions, including rigorous evaluation of project viability and progress. For instance, there have been numerous concerns about financing problem of SMEs in Nigeria due to issues such as high interest rate, collateral and other stringent measures. This outcome is consistent with the findings of Oriavwote and Eshenake (2014), and Bist (2018). 
In a similar vein, the role of stock markets in financial intermediation also proves doubtful in the Nigerian economy which can be argued as ineffective mobilization of savings for investment purpose in the Nigerian stock exchange market. Hence, this study supports the findings of Amu, Nwezeaku, and Akujuobi (2015) that growth in stock market capitalization does not have a significant impact on economic growth in Nigeria. On the other hand, this study argues the research outcome of Jalloh (2015) which finds a positive and significant relationship between stock market capitalization and economic growth among some selected African countries, including Nigeria. Additionally, this study reveals that gSAV does not have a significant impact on economic growth in Nigeria. As such, following the assertion of Loayza, Schmidt-Hebbel, and Serven (2000), this study argues that there has been low growth in income which has deterred savings and economic growth concurrently due to insufficient investment in the Nigerian economy. More so, the insignificance of gBRM on economic growth in Nigeria can be related to ineffective implementation of monetary policy in Nigeria which affirms the research outcome of Olokoyo (2011) and Ajayi and Atanda (2012). Furthemore, the insignificance of gEXR can be attributable to volalitily in exchange rate (N to USD) over the years which has caused uncertainty in the factors of production as highlighted by Katusiime, Agbola, and Shamsuddin (2016).

\section{Recommendations for Policy and Practice}

The outcome of this study supports the 'feedback hypothesis' view as the study reveals a bidirectional causality between finance and growth. Nonetheless, based on the regression result of this study, we recommend that credit to private sector should be encouraged and such credit should be invested into the productive sectors of the Nigerian economy. As such, this would tend to increase output for both export and domestic consumption. Therefore, this would concurrently improve the influence of trade openness on economic growth in the Nigerian economy, and strengthen and stabilize exchange rate. Also, conflicts between monetary and fiscal policy in Nigeria has been a major factor hindering economic growth in Nigeria (Ogbole, Amadi, \& Essi, 2011) and the CBN's lack of instrument independence (Omotor, 2009). Hence, the independence of CBN in using its monetary policy tools would trigger the effectiveness of broad money supply in enhancing economic growth in Nigeria. Furthermore, commercial banks should ensure savings of individuals and businesses are channelled to productive use in order to increase investment in the stock markets and other financial institutions.

\section{References}

Abosedra, S., \& Sita, B. (2018). Finance-growth Volatility Nexus: Evidence from Lebanon. Asian Economic and Financial Review, 8(4), 466-477. https://doi.org/10.18488/journal.aefr.2018.84.466.477

Adeniyi, O. et al. (2018). Financial Development and Economic Growth in Nigeria: Evidence from Threshold Modelling. Economic Analysis and Policy, 47, 11-21. https://doi.org/10.1016/j.eap.2015.06.003

Adeyeye, P. et al. (2015). Does Supply-leading Hypothesis hold in a Developing Economy? A Nigerian Focus. Procedia Economics and Finance, 30, 30-37. https://doi.org/10.1016/S2212-5671(15)01252-6

Adu, G., Marbuah, G., \& Mensah, J. (2013). Financial Development and Economic Growth in Ghana: Does the Measure of Financial Development Matter? Review of Development Finance, 3, 192-203. https://doi.org/10.1016/j.rdf.2013.11.001

African Development Bank. (2017). African Economic Outlook: Enterpreneurship and Industrialisation. Retrieved

from https://www.afdb.org/fileadmin/uploads/afdb/Documents/Publications/AEO_2017_Report_Full_English.pd $\mathrm{f}$

African Development Bank. (2018). Nigeria Economic Outlook. Retrieved from https://www.afdb.org/en/countries/west-africa/nigeria/nigeria-economic-outlook/

Ahmed, S., \& Ansari, M. (1998). Financial Sector Development and Economic Growth: The South-Asian Experience. Journal of Asian Economics, 9(3), 503-517. https://doi.org/10.1016/S1049-0078(99)80100-6

Ajayi, F., \& Atanda, A. (2012). Monetary Policy and Bank Performance in Nigeria: A Two-Step Cointegration Approach. African Journal of Scientific Research, 9(1), 462-476.

Akbas, Y. (2015). Financial Development and Economic Growth in Emerging Market: Boostrap Panel Causality Analysis. Theoretical and Applied Economics, XXII(3), 171-186.

Akpan, E., Nwosu, E., \& Eweke, G. (2017). Causality between Non-oil Export, Financial Sector Development and Economic Growth: Evidence from Nigeria. Journal of Mathematical Finance, 7, 39-53. https://doi.org/10.4236/jmf.2017.71002

Akpansung, A., \& Babalola, S. (2012). Banking Sector Credit and Economic Growth in Nigeria. CBN Journal of 
Applied Statistics, 2(2), 51-62.

Alabede, J. (2012). The Intervening Effect of Global Financial Condition on the Determinants of Bank Performance: Evidence from Nigeria. Accounting and Finance Research, 1(2), 161-176. https://doi.org/10.5430/afr.v1n2p161

Amu, C., Nwezeaku, N., \& Akujuobi, A. (2015). Impact of Capital Market Growth on Economic Growth and Development in Nigeria. American Journal of Marketing Research, 1(3), 93-98.

AOIOE. (2017). Nigeria Economic Recovery and Growth Plan: 2017-2020. Retrieved from http://www.acioe.com/2017/11/15/nigeria-economic-recovery-growth-plan-2017-2020-overview/

Arnold, G. (2012). Modern Financial Markets and Institutions: A Practical Perspective. England, Pearson.

Bagehot, W. (1873). Lombard Street: A Description of the Money Market. New York, E.P Dutton and Company.

Belsley, D. (1991). Conditional Diagnostics: Collinearity and Weak Data in Regression. New York, Wiley.

Bist, J. (2018). Financial Development and Economic Growth: Evidence from a Panel of 16 African and Non-African Low income Countries. Cogent Economics and Finance, 6(1449780), 1-17. https://doi.org/10.1080/23322039.2018.1449780

Calderon, C., \& Liu, L. (2003). The Direction of Causality Between Financial Development and Economic Growth. Journal of Development Economics, 72, 321-334. https://doi.org/10.1016/S0304-3878(03)00079-8

Chatterjee, S., \& Hadi, S. (2012). Regression Analysis by Example (5th ed.). New York, Hoboken, NJ.

Cheng, X., \& Degryse, H. (2010). The Impact of Bank and Non-bank Financial Instiutions on Local Economic Growth in China. Journal of Financial Services Research, 37(2-3), 179-199. https://doi.org/10.1007/s10693-009-0077-4

D'Agostino, G., Dunne, J., \& Pieroni, L. (2016). Government Spending, Corruption and Economic Growth. World Development, 84, 190-205. https://doi.org/10.1016/j.worlddev.2016.03.011

Demetriades, P., \& Hussein, K. (1996). Does Financial Development Cause Economic Growth? Time Series Evidence from 16 Countries. Journal of Development Economics, 51(1), 387-414. https://doi.org/10.1016/S0304-3878(96)00421-X

Deyshappriya, N. (2016). The Causality Direction of the Stock Market-Growth Nexus: Application of GMM Dynamic Panel Data and the Panel Ganger Non-Causality Tests. Margin: The Journal of Applied Economic Research, 10(4), 446-464. https://doi.org/10.1177/0973801016659726

Dickey, D., \& Fuller, W. (1979). Distribution of the Estimators for Autoregressive Time Series with a Unit Root. Journal of the American Statistical Association, 74, 427-431.

Fethi, S., \& Katircioglu, S. (2015). The Role of the Financial Sector in the UK Economy: Evidence from a Seasonal Cointegration Analysis. Economic Research-Ekonomska Istrazivanja, 28(1), 717-737. https://doi.org/10.1080/1331677X.2015.1084476

Ghartey, E. (2018). Financial Development and Economic Growth: Some Carribbean Empirical Evidence. Journal of Economic Development, 43(1), 49-76.

Goldsmith, R. (1969). Financial Structure and Development. New Haven, Yale University Press.

Gregorio, J., \& Guidotti, P. (1995). Financial Development and Economic Growth. World Development, 23(3), 433-448. https://doi.org/10.1016/0305-750X(94)00132-I

Hao, C. (2006). Development of Financial Intermediation and Economic Growth: The Chinese Experience. China Economic Review, 17, 347-362. https://doi.org/10.1016/j.chieco.2006.01.001

Hassan, M., Sanchez, B., \& Yu, J. (2011). Financial Development and Economic Growth: New Evidence from Panel Data. The Quarterly Review of Economics and Finance, 51, 88-104. https://doi.org/10.1016/j.qref.2010.09.001

Hendry, D., \& Juselius, K. (2000). Explaining Cointegration Analysis: Part II. https://doi.org/10.5547/ISSN0195-6574-EJ-Vol21-No1-1

IMF. (2017). List of Members. Retrieved from https://www.imf.org/external $/ \mathrm{np} / \mathrm{sec} / \mathrm{memdir} / \mathrm{memdate} . \mathrm{htm}$

Jalloh, M. (2015). Does Stock Market Capitalization Influences Economic Growth in Africa? Evidence from Panel Data. Applied Economics and Finance, 2(1), 91-101. http://doi:10.11114/aef.v2i1.641 
Kar, M., Nazlioglu, S., \& Agir, H. (2011). Financial Development and Economic Growth Nexus in the MENA Countries: Bootstrap Panel Granger Causality Analysis. Economic Modelling, 28, 685-693. http:// https://doi.org/10.1016/j.econmod.2010.05.015

Katusiime, L., Agbola, F., \& Shamsuddin, A. (2016). Exchange rate volatility-economic growth nexus in Uganda. Applied Economics, 48(26), 2428-2442. https://doi.org/10.1080/00036846.2015.1122732

King, R., \& Levine, R. (1993). Finance and Growth: Schumpeter Might be Right. Quartely Journal of Economics, 108(3), 717-738. https://doi.org/10.2307/2118406

Korkmaz, S. (2015). Impact of Bank Credits on Economic Growth and Inflation. Journal of Applied Finance and Banking, 5(1), 51-63.

Kumar, S. (2014). Financial Development as an Instrument of Economic Growth in India: Evidence from Cointegration and Causality Analysis. IUP Journal of Applied Economics, 13(4), 28-41.

Kyophilavong, P., Uddin, G., \& Shahbaz, M. (2016). The Nexus Between Financial Development and Economic Growth in Lao PDR. Global Business Review, 17(2), 303-317. https://doi.org/10.1177/0972150915619809

Levine, R. (1997). Financial Development and Growth: Views and Agenda. Journal of Economic Literature, 35(2), 688-726.

Levine, R. (2002). Bank-based or Market-based Financial Systems: Which is better? Journal of Financial Intermediation, 11(4), 398-428. https://doi.org/10.1006/jfin.2002.0341

Levine, R., Loayza, N., \& Beck, T. (2000). Financial Intermediation and Growth: Causality and Causes. Journal of Monetary Economics, 46(1), 31-77. https://doi.org/10.1016/S0304-3932(00)00017-9

Liang, H., \& Reichert, A. (2012). The Impact of Banks and Non-Bank Financial Institutions on Economic Growth. The Service Industries Journal, 32(5), 699-717. https://doi.org/10.1080/02642069.2010.529437

Lin, S. (1994). Government Spending and Economic Growth. Applied Economics, 26, 83-94. https://doi.org/10.1080/00036849400000064

Loayza, N., Schmidt-Hebbel, K., \& Serven, L. (2000). Saving in Developing Countries: An Overview. The World Bank Economic Review, 14(3), 393-414. https://doi.org/10.1093/wber/14.3.393

Lu, C., \& Shen, C. (2012). Bank Lending and Economic Growth of Chinese Cities. China and World Economy, 20(2), 59-79. https://doi.org/10.1111/j.1749-124X.2012.01280.x

Lucas, R. (1988). On the Mechanisms of Economic Development. Journal of Monetary Economics, 22(1), 3-42. https://doi.org/10.1016/0304-3932(88)90168-7

Mahran, H. (2012). Financial Intermediation and Economic Growth in Saudi-Arabia: An Empirical Analysis, 1968-2010. Modern Economy, 3(1), 626-640. https://doi.org/10.4236/me.2012.35082

Mamman, A., \& Hashim, Y. (2014). Impact of Bank Lending on Economic Growth in Nigeria. Research Journal of Finance and Accounting, 5(18), 174-182.

Mankiw, N. (2004). Principles of Economics (3rd ed). Mason, OH, Thomson-South-Western.

Marashdeh, H., \& Al-Malkawi, H. (2014). Financial Deepening and Economic Growth in Saudi Arabia. Journal of Emerging Market Finance, 13(2), 139-154. https://doi.org/10.1177/0972652714541339

Mckinnon, R. (1973). Money and Capital in Economic Development. Washington, DC, The Brookings Institution.

Modebe, N., \& Ezeaku, H. (2016). Relationship between Financial Development and Economic Growth in Nigeria. International Journal of Economics and Financial Issues, 6(4), 1842-1850.

Modebe, N., Ugwuegbe, S., \& Ugwuoke, R. (2014). The Impact of Bank Credit on the Growth of Nigerian Economy: A Co-Integration Approach. Research Journal of Finance and Accounting, 5(10), 87-95.

Mueller, D. (1979). Public Choice. Cambridge, Cambridge University Press.

Nasir, H., Majeed, S., \& Aleem, A. (2018). Does Financial Development Leads Economic Growth? Evidence from Emerging Asian Markets. Asian Economic and Financial Review, 8(5), 599-617. https://doi.org/10.18488/journal.aefr.2018.85.599.617

Ndako, U. (2010). Financial Development and Economic Growth: Evidence from Nigeria. The IUP Journal of Financial Economics, 8(4), 37-58. 
Ndlovu, G. (2013). Financial Sector Development and Economic Growth: Evidence from Zimbabwe. International Journal of Economics and Financial Issues, 3(2), 435-446.

Nielsen, B. (2001). Order Determination in General Vector Autoregressions. Working Paper, Department of Economics, University of Oxford and Nuffield College.

Nwanyanwu, O. (2010). An Analysis of Banks' Credit on the Nigerian Economic Growth. Jos Journal of Economics, 4(1), 23-45.

Nyasha, N., \& Odhiambo, M. (2015). Do Banks and Stock Markets Spur Economic Growth? Kenya's Experience. International Journal of Sustainable Economy, 7(1), 54-65. https://doi.org/10.1504/ijse.2015.066406

Odedokun, M. (1996). Alternative Econometric Approaches for Analysing the Role of the Financial Sector in Economic Growth: Time-series Evidence from LDCs. Journal of Development Economics, 50(1), 119-146. https://doi.org/10.1016/0304-3878(96)00006-5

Odedokun, M. (1998). Financial Intermediation and Economic Growth in Developing Countries. Journal of Economic Studies, 25, 137-159. https://doi.org/10.1108/01443589810215351

Ogbole, F., Amadi, N., \& Essi, D. (2011). Fiscal Policy: Its Impact on Economic Growth in Nigeria (1970 to 2006). Journal of Economics and International Finance, 3(6), 407-417.

Ogbonna, I. et al. (2013). Financial Development-Growth Nexus in Nigeria: Empirical Investigation based on Vector Autoregressive (VAR) Approach. Journal of Economics and Finance, 1(5), 58-71. https://doi.org/10.9790/5933-0155871

Olokoyo, F. (2011). Determinants of Commercial Banks' Lending Behaviour in Nigeria. International Journal of Financial Research, 2(2), 61-72. https://doi.org/10.5430/ijfr.v2n2p61

Omotor, D. (2009). The Nigerian Economy and Monetary Policy: Some Simple Empirics. Retrieved from http://mpra.ub.uni-muenchen.de/22672/

Oriavwote, V., \& Eshenake, S. (2014). An Empirical Assessment of Financial Sector Development and Economic Growth in Nigeria. International Review of Management and Business Research, 3(1), 139-149.

Orji, A., Imelda, O., \& Mba, P. (2015). Financial Liberalization and Output Growth in Nigeria. International Journal of Economic and Financial Issues, 5(1), 297-311.

Pan, L., \& Mishra, V. (2018). Stock Market Development and Economic Growth: Empirical evidence from China. Economic Modelling, 68, 661-673. https://doi.org/10.1016/j.econmod.2017.07.005

Patrick, H. (1966). Financial Development and Economic Growth in Underdeveloped Countries. Economic Development and Cultural Change, 34(1), 174-189. https://doi.org/10.1086/450153

Paulsen, J. (1984). Order Determination of Multivariate Autoregressive Time Series with Unit Roots. Journal of Time Series Analysis, 5, 115-127. https://doi.org/10.1111/j.1467-9892.1984.tb00381.x

Pavelescu, F. (2008). Gross Capital Formation and Economic Growth During Early 2000's in EU-Member and Candidates States. Romanian Economic Journal, 1, 1-12.

Pradhan, R. (2018). Development of Stock Market and Economic Growth; the G-20 Evidence. Eurasian Econ Rev., 1-21. https://doi.org/10.1007/s40822-018-0094-4

Robinson, J. (1952). The Generalization of the General Theory, the Rate of Interest and other Essays. London, Macmillan.

Rogoff, K. (2016). What's Behind the Drop in Oil Prices?. Retrieved from https://www.weforum.org/agenda/2016/03/what-s-behind-the-drop-in-oil-prices/

Rousseau, P., \& Wachtel, P. (1998). Financial Intermediation and Economic Performance: Historical Evidence from Industrial Countries. Journal of Money, Credit and Banking, 30(4), 657-678. https://doi.org/10.2307/2601123

Schumpeter, J. (1911). A Theory of Economic Development. Cambridge, Harvard University Press.

Seth, A. (2007). Granger Causality. https://doi.org/10.4249/scholarpedia.1667

Shaw, E. (1973). Financial Deepening in Economic Development. New York, Oxford Univeristy Press.

Templars. (2017). The Nigerian Economic Recovery and Growth Plan: A Renewed Hope for Revival? Retrieved from 
https:/www.templars-law.com/wp-content/uploads/2017/04/Nigerian-Economic-Recovery-Growth-Plan-ARenewed-Hope-for-Revival-.pdf

Trading Economics. (2018). Nigeria GDP Annual Growth Rate. Retrieved from https://tradingeconomics.com/nigeria/gdp-growth-annual

Tsay, R. (1984). Order Selection in Nonstationary Autoregressive Models. Annals of Statistics, 12, 1425-1433. https://doi.org/10.1214/aos/1176346801

Uddin, G., Sjo, B., \& Shahbaz, M. (2013). The Causal Nexus between Financial Development and Economic Growth in Kenya. Economic Modelling, 35, 701-707. https://doi.org/10.1016/j.econmod.2013.08.031

Yang, Y., \& Yi, M. (2008). Does Financial Development Cause Economic Growth? Implication for Policy in Korea. Journal of Policy Modelling, 30, 827-840. https://doi.org/10.1016/j.jpolmod.2007.09.006

Zhang, J., Wang, L., \& Wang, S. (2012). Financial Development and Economic Growth: Recent Evidence from China. Journal of Comparative Economics, 40, 393-412. https://doi.org/10.1016/j.jce.2012.01.001

\section{Copyrights}

Copyright for this article is retained by the author(s), with first publication rights granted to the journal.

This is an open-access article distributed under the terms and conditions of the Creative Commons Attribution license (http://creativecommons.org/licenses/by/4.0/). 